\title{
An Examination on the Chinese Students' Rationales to Receive their Higher Education in the U.S.
}

\author{
Chiang-Nan Chao ${ }^{1, *}$ \\ ${ }^{1}$ The Peter J. Tobin College of Business, St. John's University, USA \\ *Correspondence: The Peter J. Tobin College of Business, St. John's University, USA. E-mail: \\ chiangnanchao@gmail.com
}

Received: April 4, 2017

Accepted: April 28, 2017 Online Published: June 6, 2017

doi:10.5430/wje.v7n3p41

URL: https://doi.org/10.5430/wje.v7n3p41

\begin{abstract}
This research attempts to explore the rationales why so many Chinese students choose to study abroad and why the United States is their preferred destination. This population is small, but a vital component of university life at many colleges and a much needed source of financial revenue. A total of 380 students completed a questionnaire yielding 138 usable responses. Specifically, the rationale behind Chinese students' rationales for attending colleges in the U.S is explored. The results indicate that Chinese students are seeking education with a worldview, and opt to break from the Chinese system of learning. Although choosing to study in the U.S. is an academic endeavor the rationales behind that choice is not solely for academics. A better understanding of the Chinese students' rationales can help academicians and university administrators to better target at this population and serve them better.
\end{abstract}

Keywords: international education; international students; international students' decision making for enrolling in the U.S. schools

\section{Introduction}

In the past eleven years from $2006 / 07$ to $2015 / 16$, the total international students in the U.S. rose 526,670 to $1,043,839$, an increase of about $98 \%$, or about $4.8 \%$ of the total student enrollment in the U.S. During the same period, the total Chinese students in the U.S. rose from 67,723 to 328,547 , representing a $385 \%$ increase, according to Open Door report. China has become the largest single source of international students, making up a commanding 31.5 percent of all international students in the United States in 2015/16. This strong growth presents important export opportunities for U.S. colleges and universities, however, between 2014/15 and 2015/15 academic years, this growth rate decreased to about eight percent, following more than double digit growth rate in prior eight years. These international students and their families contributed US $\$ 35.8$ billion to the US economy U.S. in 2015/16 (Report of Open Door, 2016). Attracting the best students from around the world has become a large and growing global export opportunity (Zawacki-Richter \& Bedenlier, 2015; Lumby \& Foskett, 2015).

The rapid growth of the Chinese students in the U.S. universities raises an urgency for a better understanding of these students' rationales and identify effective ways to serve this population, not only as an educational endeavor, but also a global business strategy, since the returned students would have political, economic, and leadership impacts to the second largest economy in the world. This research, using an empirical approach, focuses on the Chinese students' rationales, in order to provide some insightful glimpses for educational institutes. 


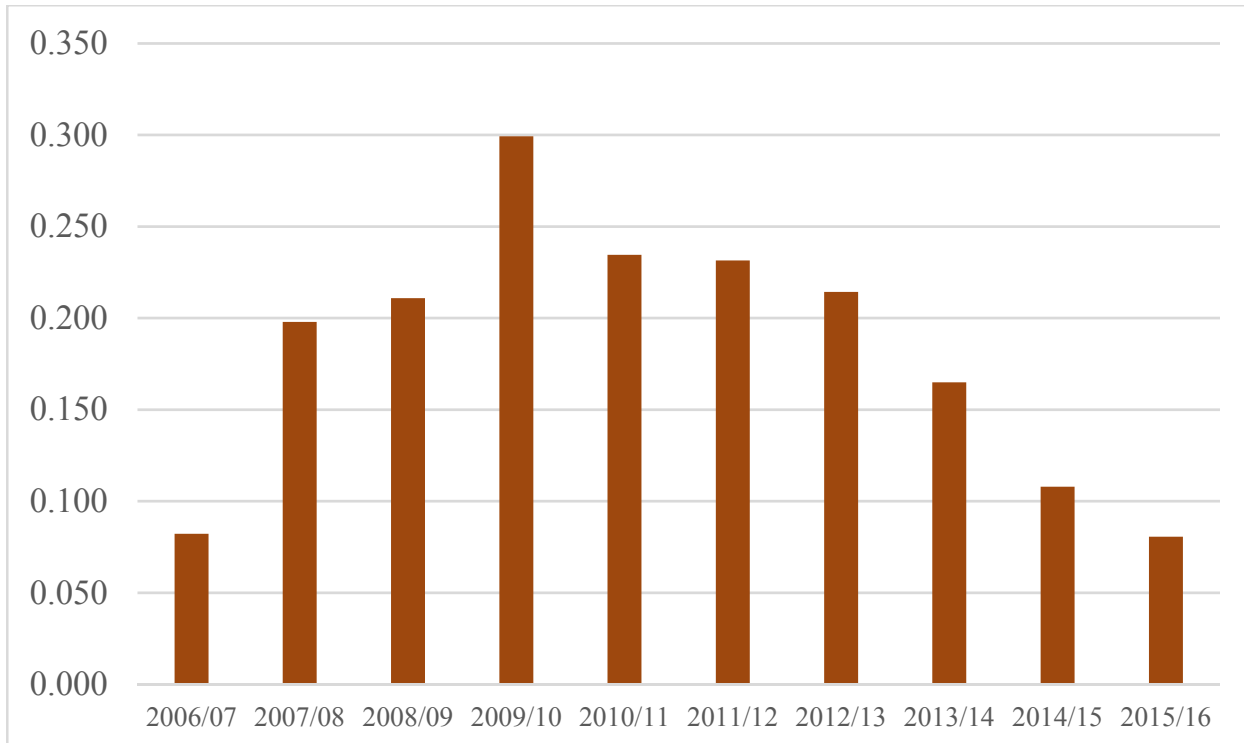

Figure 1. The Growth Rate of Chinese Students in the U.S., 2006-2016

Source: Open Doors Data, 2016.

\section{Review of Literature}

For thousands of years, education has been placed as a top priority by Chinese families. With China's economic accomplishments during the past decades and a shrink of family size (only one child per family), sending children to universities abroad has become practically reachable. In the past decade, many Chinese parents are tired of an education system that focuses mainly on academic scores at the expense of pupil's overall development, negatively affect by the Chinese educational system's corruption and briberies. Many Chinese parents seriously believe to send their kids abroad for higher education would be better for their kids' future (Yan, 2015). They make the U.S. No. 1 destination, not only because the U.S. has the capacity to absorb large number of international students and is one of the major English speaking countries, but also U.S. universities offer higher quality and a large variety of academic programs. Students from China value U.S. colleges and universities for their high quality education that stresses interdisciplinary approaches, student participation and critical thinking. Businesses employers in China value U.S. degrees highly, while students' parents have the means to afford (Gates, 2012). Unlike American students who are often eligible for in-state tuition rates, financial aid and numerous scholarships, most Chinese students pay full tuitions which could run about $\$ 200,000$ just for tuition and fees over four-year period (Zhao, 2013). In China, high school students need to pass the Chinese National College Entrance Examinations to be admitted in Chinese colleges and universities. The Chinese National College Entrance Examinations are to be very competitive, but rigid. In the recent years, many believe that the Chinese educational system is corruptive. Chinese students and their parents judge U.S. schools to be a better choice for the higher education (Ark, et al 2008). While the benefits of studying abroad go beyond the degree itself. Several recent studies have investigated the motivations, incentives, and decisions for the Chinese students to study overseas. The study by Bodycott (2009) reveals that some foreign institutions have to understand not just the psychology and the motivations of Chinese students, but also those of their parents. The decisions and motivations may not be the only factors responsible for the choice leading Chinese students to decide to come to the U.S. A study by Bodycott (2009) focuses on the motivations of both parents and students. The study finds that parents' motivations are different from those of their children in terms of what they seek in a university with the range of programs available being the only common concern.

The benefits of studying abroad are felt both by individuals and entire nations. For these reasons educators and researchers are interested in the decision making considerations that Chinese students have for their endeavor for studying in the U.S. Of all international students, about $65 \%$ of source of funding comes from students' families. Meanwhile, many U.S. universities are facing an increasingly tough financial difficulty with a shortage of domestic students, a sharp decrease in corporate support, and declines in government educational funding. International students with cash to spend may bridge that financial gap (Joseph, 2012; WES Report, 2015). 
Glass (2012) suggests that international students who participate in leadership programs, community service, and campus-organized diversity discussions, interact with people from diverse cultural backgrounds, and take courses with materials on race and ethnicity report greater levels of learning and development. However, that study focused on learning outcomes rather than motivation factors leading international students to study in the U.S.

When looking into the Chinese applicants' backgrounds, many schools find some outstanding characteristics the Chinese applicants possess. First, many are China's best students who are probably aware that if they attend universities in China, they may not able to go to the best universities in the world. For example, among top 100 universities around the world, only two Chinese universities are ranked in 53th and 57th by the U.S. News and World Report (2017). Second, unlike U.S. institutions that value candidates who present themselves as unique, their Chinese counterparts want students who excel on entrance exams that require years of rote learning and possess a strong grasp of math and science. Third, these young individuals are ambitious and many want to go to Ivy League schools, a symbol for those parents who raise their children successfully. Fourth, they desire to learn more about critical thinking, and very importantly, they want to be exposed to things aside from just test taking (Henze \& Zhu, 2012; Taylor, 2012; Wu, 2014).

Besides economic wellbeing, many Chinese students decide to study abroad because they believe there is a better quality education in foreign countries. Several other factors may also influence the decision making for Chinese students to study abroad. First, more Chinese citizens are completing college and thus eligible to apply to grad school. Second, up to 1,000 universities in France, Italy, and other 14 popular overseas destinations for Chinese applicants now accept the Chinese national college entrance test scores or "Gaokao" scores as admission criteria Ybanez, 2015). Third, many U.S. schools are recruiting more aggressively overseas, marketing their programs to a wider talent pool. Word of mouth then fuels the trend, as once some students attend a program; they recommend it to friends back at home. Many schools in the U.S. have set up their gateway offices in China, i.e. Columbia University and Ohio State University. Meanwhile, new specialized master's programs appeal to students, particularly those from China, eager to delve deeper into a single subject and gain a credential to compete with the growing population of educated young adults (Albrecht, et al 2012; Ozturgut \& Murphy, 2009; Yan, 2015).

The top fields of studies in the 2015/16 year, 19\% of Chinese students in the U.S. are enrolled business/management, the fields better enable these students find employments in China (Ortiz, Chang, \& Fang, 2015). Figure 2 presents the major fields of study for the Chinese students in the U.S. (Open Door Report, 2016).

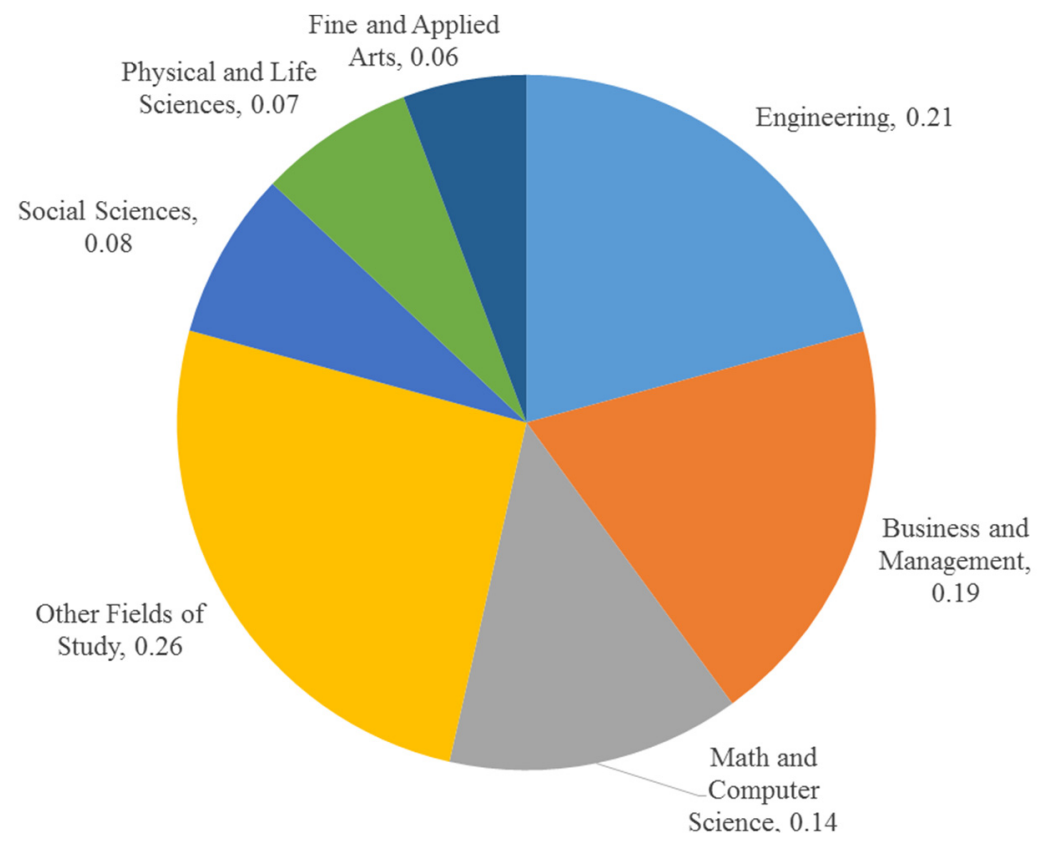

Figure. 2. Major Fields of Studies for Chinese Students in the U.S., 2016

Source: Open Doors Data, 2016 
Several studies have examined the motivations and decisions for Chinese students to study overseas. The study by Bodycott (2009) reveals that some foreign institutions have to understand not just the psychology and the needs of Chinese students, but also those of their parents. Their decisions and needs may not be the only factors responsible for the choice leading Chinese students to decide to come to the U.S. The education being offered, (along with the way the institution is marketed), should effectively be aligned with China's requirements for development.

The research work by Chao and Hegarty (2014) and Chao, et al (2017) focuses on the Chinese students' motivations and motivations for studying in the U.S. The results indicate that Chinese students are seeking education with a global view and opt to break from the traditional Chinese learning system. Their researches explore decisions Chinese students make on whether or not to study in the United States. Their research investigates the decision making process that leads to Chinese students to choose the United States as their preferred destination, thus offering a better understanding of how closely the reality of studying in the U.S. compared to these students' motivations. This research attempts to investigate the Chinese students' decision making process, hopefully to gain a further understanding of the decision making process, and provide a better quality education to serve this market segment.

\section{Method}

With the focal questions in mind, this research explores Chinese students' decision making considerations for studying in the U.S. A survey questionnaire was developed to investigate the issues related to the subject of this study: what are the important decision considerations for Chinese students to leave their home country and study in the U.S. The following variables are developed from literature reviews.

\subsection{Variable Selection}

The following variables serve as decisions that affect Chinese students in their decision-making for studying abroad, from the literature review.

1). Gain a new perspective on my own country;

2). Can attend a better school overseas, but not able to attend the schools I want due to China National College Entry Exam;

3). It is easy to be admitted by a foreign school;

4). It is also costly if I study in my home country;

5). My friends have gone abroad, so I would;

6). I want to be away from my country;

7). I must study abroad because my parents' wish;

8). There are more fields of studies offered by foreign schools;

9). Political easiness in programs abroad;

10). Better living conditions, housing, eating, and environmental, i.e. clean air, etc;

11). The educational system is better overseas.

\subsection{Hypothesis, Test of Hypothesis, and Sampling}

The hypotheses for this research are to find if there are any significant differences in the Chinese students' decisions for choosing to study in the U.S. rather than in China

Hypothesis $_{1}$ : There is no significant difference for Chinese students to gain a new perspective between China and the U.S.

Hypothesis: $\quad$ There is no significant difference for Chinese students to attend a better school either in China or in the U.S.

Hypothesis: $\quad$ There is no significant difference for Chinese students to be admitted by a US school and a Chinese school.

Hypothesis: $\quad$ There is no significant difference for Chinese students to attend schools either in China or in the U.S. as far as cost is concerned.

Hypothesis: $\quad$ There is no significant difference for Chinese students to attend school either in China or in the U.S., because their friends have gone. 
Hypothesis 6 : $\quad$ There is no significant difference for Chinese students to attend school either in China or in the U.S., because these Chinese students want to be away from their home country.

Hypothesis7: There is no significant difference for Chinese students for where their parents wish them to study.

Hypothesiss: $\quad$ There is no significant difference for Chinese students to find more fields of studies either in China or in the U.S.

Hypothesisg: $\quad$ There is no significant difference for Chinese students to find political easiness in programs either in China or in the U.S.

Hypothesis 10 : There is no significant difference for Chinese students living conditions, housing, eating, and environmental, i.e. clean air, etc. either in China or in the U.S.

Hypothesis ${ }_{11}$ : There is no significant difference for Chinese students, as the educational systems in China and the U.S. are the same.

Alternatively, there are significant differences in each of these hypotheses.

Due to the nature of this empirical study, the questionnaires were distributed to Chinese students in two large university campuses in the Northeast of the United States for a convenient sampling. The respondents were asked to evaluate the selected variables in a five point Likert scale, with $5=$ most important, $4=$ important, $3=$ neutral, $2=$ not important, and $1=$ least important.

One sample Student's $t$-test is used to test the hypotheses. A $t$-test is any statistical hypothesis test in which the test statistic follows a Student's $t$ distribution if the null hypothesis is supported. It is most commonly applied when the test statistic would follow a normal distribution if the value of a scaling term in the test statistic is known. The one sample $t$-test requires that the dependent variable follow a normal distribution. When the number of subjects in the experimental group is 30 or more, the central limit theorem shows a normal distribution can be assumed. If the number of subjects is less than 30 , the researcher should plot the results and examine whether they appear to follow a normal distribution. If the distribution appears to be non-normal, and/or if the number of test cases is significantly less than 30, then a one sample median test, which does not require a normal distribution, should be used to test the hypothesis (Conover, 1980; Davis and Cosenza, 1985; Hamburg, 1977; SPSS $^{\mathrm{X}}$, 2002; Wikipedia, 2012). Five percent of the $t$-Tests one tailed probability level was selected to signify the differences between preferences. When the scaling term is unknown and is replaced by an estimate based on the data, the test statistic (under certain conditions) follows a Student's $t$ distribution. The estimate value for testing hypotheses in this study is 3 , which is neutral. It shows no differences between studying either in China or in the U.S.

\section{Results and Issues}

\subsection{Results}

Over 380 respondents were surveyed, with 138 completed responded for analyses, representing 36.5 percent of the total surveyed. Table 1 presents the general background information of the respondents.

Table 1. Backgrounds of the Respondents

\begin{tabular}{llr}
\hline Variables & Groups & Valid \% \\
\hline 1. Age & $<18$ & 5.9 \\
& $18-35$ & 92.6 \\
& $35-50$ & 1.5 \\
2. gender & male & 55.6 \\
3. Family annual income & female & 44.4 \\
& $<\mathrm{US} \$ 35 \mathrm{k}$ & 31.3 \\
& US\$35-50k & 25.4 \\
& US\$50-75k & 14.9 \\
& $>\mathrm{US} \$ 75 \mathrm{k}$ & 28.4 \\
\hline
\end{tabular}




\begin{tabular}{llr}
\hline Variables & Groups & Valid \% \\
\hline 4. Education & college & 65.2 \\
& master's & 29.6 \\
& doctoral & 5.2 \\
5. Marital status & married & 8.9 \\
& single & 91.1 \\
& parents & 59.3 \\
6. Sources of financial supports & own & 5.2 \\
& scholarship or GA & 20.7 \\
& combined & 14.1 \\
7. Number years studied in the U.S. & $<1$ year & 13.3 \\
& 1 year & 8.9 \\
& $1-2$ years & 16.3 \\
& $>2$ years & 61.5 \\
\hline
\end{tabular}

Source: original

It is noticeable that $28.4 \%$ of the Chinese students who took the survey have a family income over US\$75K a year equivalent, and most of the students were born after 1978 when the one child per family policy was initiated (Healthland.time, 2013). About 65\% of the students' financial supports is from their parents and their own. More than 60 percent of the respondents have already studied in the U.S. for over two years and therefore have had ample time to affirm their rationales for leaving China.

Table 2 presents the test results of One-Sample $t$-Test, with mean differences, $t$ values, degrees of freedom, and two tailed significances of these tests.

Table 2. One-Sample t-Test Results, Test Value $=3$

\begin{tabular}{llllr}
\hline Variables & Mean & & \multicolumn{1}{c}{$\begin{array}{c}\text { Sig. } \\
\text { (2-tailed) }\end{array}$} \\
\hline 1. Gain a new perspective on my own country & Diff & $t$ & $d f$ & $\mathbf{0 . 0 0 0}$ \\
2. Can attend a better school overseas, but not able to attend the & & & & \\
schools I want due to Gaokao. & 0.039 & 0.302 & 126 & 0.764 \\
3. It is easy to be admitted by a foreign school. & $\mathbf{- 0 . 2 9}$ & $\mathbf{- 2 . 6 9 8}$ & $\mathbf{1 2 9}$ & $\mathbf{0 . 0 0 8}$ \\
4. It is also costly if I study in my home country. & $\mathbf{- 0 . 5 5}$ & $\mathbf{- 5 . 0 7 0}$ & $\mathbf{1 2 9}$ & $\mathbf{0 . 0 0 0}$ \\
5. My friends have gone abroad, so I would & $\mathbf{- 0 . 6 6}$ & $\mathbf{- 5 . 6 2 7}$ & $\mathbf{1 3 0}$ & $\mathbf{0 . 0 0 0}$ \\
6. I want to be away from my country & $\mathbf{- 0 . 6 5}$ & $\mathbf{- 5 . 2 7 4}$ & $\mathbf{1 2 9}$ & $\mathbf{0 . 0 0 0}$ \\
7. I must study abroad because my parents' wish & $\mathbf{- 0 . 6 1}$ & $\mathbf{- 5 . 3 4 2}$ & $\mathbf{1 2 9}$ & $\mathbf{0 . 0 0 0}$ \\
8. There are more fields of studies offered by foreign schools. & 0.008 & 0.063 & 129 & 0.950 \\
9. Political easiness in programs abroad & $\mathbf{- 0 . 3 3}$ & $\mathbf{- 2 . 9 7 1}$ & $\mathbf{1 2 8}$ & $\mathbf{0 . 0 0 4}$ \\
10. Better living conditions, housing, eating, and environmental, i.e. & & & & \\
clean air, etc. & -0.12 & -0.996 & 130 & 0.321 \\
11. The educational system is better overseas. & $\mathbf{0 . 3 8 2}$ & $\mathbf{3 . 0 7 2}$ & $\mathbf{1 3 0}$ & $\mathbf{0 . 0 0 3}$ \\
\hline
\end{tabular}

Source: original 


\subsection{Conclusion: Managerial Implications and Recommendations}

The test results of One-Sample $t$-Test reject eight null hypotheses:

\section{Gain a new perspective on my own country}

3. It is easy to be admitted by a foreign school.

4. It is also costly if I study in my home country.

5. My friends have gone abroad, so I would

6. I want to be away from my country

7. I must study abroad because my parents' wish

\section{Political easiness in programs abroad}

\section{The educational system is better overseas.}

The mean differences as compared to the test value of 3 which is neutral tell the researchers how relatively important of these variables. The results show that two variables, 1. Gain a new perspective on my own country and 11. The educational system is better overseas, show the positive mean differences, which mean the respondents view these variables more important. To supplement the survey, interviews were conducted. Many respondents indicate that Chinese Higher Education System lacks of innovation, and the students have to memorize the doctrines, rather than to find new ways of doing things. This gives credits to many US colleges that give Chinese students a worldwide view and encourage them to innovate.

With regard to the other nine variables: 2. Can attend a better school overseas, but not able to attend the schools I want due to China National College Entry Exam; 3. It is easy to be admitted by a foreign school; 4 . It is also costly if I study in my home country; 5 . My friends have gone abroad, so I would; 6 . I want to be away from my country; 7. I must study abroad because my parents' wish; 8 . There are more fields of studies offered by foreign schools; 9. Political easiness in programs abroad; 10. Better living conditions, housing, eating, and environmental, i.e. clean air, etc, the respondents express that these are less important. This would suggest that these variables are less important for the Chinese students' decisions for studying in the U.S. Some respondents indicate that it is as difficult as they apply for admissions at Chinese universities, especially the top 200 universities. Many indicate that the cost of studying at Chinese universities has rapidly increased in the past years. "Catch up with Jones" is a fallacy for the Chinese students, rather than an important rationale for their study aboard. These respondents indicate that there were aware that the job opportunities for foreign students were not good in the U.S., so the overwhelm majority need to return to China for jobs. The respondents also indicate that they come to the U.S. not for their parents' wishes, as they want to do at their own will. For Variable 9, some respondents indicate that in the recent years, the Chinese universities ease political required courses.

The test results of One-Sample t-Test accept three null hypotheses: 2. Can attend a better school overseas, but not able to attend the schools I want due to China National College Entry Exam; 8. There are more fields of studies offered by foreign schools; 10. Better living conditions, housing, eating, and environmental, i.e. clean air, etc. In other words, the acceptances of these hypotheses recommend that the Chinese students do not view these issues differently. Many respondents indicate that the Chinese educational system is rigid, the choices of programs of studies are restrictive, as once they enroll in one program, it is not easy to switch to other programs.

What more comes through from this research is that non-academic reasons are primarily driving Chinese students to study in the U.S. Cultural aspects and desires to gain a non-Chinese world perspective emerge as primary rationales for study in the U.S. This may be due to the China's emergence as a global economy and to the understanding of the global business. These rationales are consistent with the realities of all affluent middle classes who have moved beyond daily sustenance and have achieved long term security.

\subsection{Limitations and Future Research}

While this study is limited by sample size and confined to Chinese students studying at only two universities in the Northeast America it does provide some glimpse for future researcher to build upon.

The author conducted a special research tour recently in China to interview with the parents (some are grandparents) who have their children in the U.S. or plan to send their children to, indicate that they believe that higher education overseas is much better. As long as they can afford, their first choice is to let their children study overseas. Academic research on the rationales of international student populations ( $4 \%$ of the total US college students), particularly Chinese students (over 1\% of the total US college students) in the U.S. is limited. While much has been written in 
terms of their numbers, however, how universities accommodate Chinese students is limited. It is imperative in servicing this market segment that universities first need to better understand the rationales then colleges and universities in the U.S. can build programs to cater to the long term facilitation of this segment market.

Future empirical studies may also focus the life style and living of these Chinese students in the U.S. or elsewhere, as many participate in this study, live together, and speak their own language, and it seems there is a battier between this market segment and the rest of local and international students. A further recommendation would be to look at any major differences between undergraduate and graduate Chinese students as well as differences between graduate Chinese who have completed bachelor degrees in the U.S. and those who haven't.

In the future, researchers will need to know more about: what are the expectations of these Chinese students when they land in the U.S.? Are their expectations met during their studies or after their studies? If their expectations are not met, what educators in the U.S. schools need to do? A demographic of this size cannot be ignored and needs to be better understood.

\section{References}

Albrecht, C., Malagueno, R. Holland, D., \& Sanders, M. (2012). A Cross-Country Perspective on Professional Oversight, Education Standards and Countries' Perceived Level of Corruption. Cross Cultural Management: An International Journal, 19(4), 433-454.

Ark, B. V., O'Mahony, M., \& Timmer, M. P. (2008). The Productivity Gap between Europe and the United States: Trends and Causes. Journal of Economic Perspectives, 22(1), 25-44. https://doi.org/10.1257/jep.22.1.25

Bodycott, P. (2009). Choosing a higher education study abroad destination: What mainland Chinese parents and students rate as important. Journal of Research in International Education, 8, 349-373. https://doi.org/10.1177/1475240909345818

Chao, C., \& Hegarty, N. (2014). Driving Forces which Enthuse the Continuous Growth of Chinese Students in U.S. Colleges: A Preliminary Study on Chinese Students' Motives. Journal of Academic Administration in Higher Education, 10(2), 27-34.

Chao, C., Hegarty, N., Angelidis, J., \& Lu, V. F. (2017). Chinese Students' Motivations for Studying in the U.S.--A Preliminary Research. Journal of International Students, 7(2), 257-269.

Conover, W. J. (1980). Practical Nonparametric Statistics (2nd ed.). New York: John Wiley and Sons, pp. 213-337 and 344-384.

Davis, D., \& R. M. Cosenza. (1985). Business Research for Decision Making. Boston: Kent Publishing Company.

Gates, M. (2012). China's growing middle class means influx of students for U.S. colleges. USA Today, January 11.

Glass, C. R. (2012, July). Educational Experiences Associated with International Students' Learning, Development, and Positive Perceptions of Campus Climate. Journal of Studies in International Education, 16, 228-251. https://doi.org/10.1177/1028315311426783

Hamburg, M. (1977). Statistical Analysis for Decision Making (2nd Ed.). New York: Harcourt Brace Jovanovich, Inc., pp. 219538.

Healthland.Time. (2013). Retrieved from http://healthland.time.com/2013/01/10/little-emperors/

Henze, J., \& Zhu, J. (2012). Current research on Chinese students studying abroad, Research in Comparative and International Education, 7(1), 90-104. https://doi.org/10.2304/rcie.2012.7.1.90

Joseph, F. (2012). Overseas colleges fight for Chinese students. CNTV, October 19.

Lumby, J., \& N. Foskett (2015). Internationalization and Culture in Higher Education. Journal of Studies in International Education, January 16, 2015

Ortiz, A., Chang, L., \& Fang, Y. (2015). International Student Mobility Trends 2015: An Economic Perspective, Social Science Research Network. Retrieved February 2, from http://wenr.wes.org/2015/02/international-student-mobility-trends-2015-an-economic-perspective/

Ozturgut, O., \& Murphy, C. (2009). Literature vs. practice: challenges for international students in the U.S. International Journal of Teaching and Learning in Higher Education, 22(3), 374-385.

Report of Open Door, 
http://www.iie.org/en/Research-and-Publications/Open-Doors/Data/International-Students\#.WMqyCE2gs5s, November 14, 2016.

SPSS $^{\mathrm{X}}$, Advanced Statistics, 7.5. Chicago, IL: SPSS Inc. 2002.

Taylor, A. (2012). Three Reasons China's Students are Desperate to Study in America. Business Insight, October.

WES Report: International trend in higher education, an Oxford Report, (2015). Retrieved from: https:/www.ox.ac.uk/sites/files/oxford/International\%20Trends\%20in\%20Higher\%20Education\%202015.pdf;

Report of Open Door, 2016, Retrieved November 14, 2016 from http://www.iie.org/en/Research-and-Publications/Open-Doors/Data/International-Students\#.WMqyCE2gs5s

Wikipedia, student t-Test. Retrieved from Wikipedia, $2012 \mathrm{http} / /$ en.wikipedia.org/wiki/Student's_t-test; Source: http://www-users.cs.umn.edu/ ludford/Stat_Guide/1_Sample_t.htm

Wu, Q. (2014). Motivations and Decision-Making Processes of Mainland Chinese Students for Undertaking Master's Programs Abroad. Journal of Studies in International Education, 18(5), 426-444. https://doi.org/10.1177/1028315313519823

Yan, A. (2015). Why Chinese parents are sending their children abroad to study at a younger age, South China Morning Post. $\quad$ Retrieved March 25, 2015 from http://www.scmp.com/news/china/article/1747075/why-mainland-parents-are-sending-their-children-abroad-stu dy-younger-age?page $=$ all

Ybanez,

A.

(2015).

Retrieved

from http://en.yibada.com/articles/41077/20150626/italy-france-now-accept-gaokao-scores.htm\#ixzz3k81uYq4i

Zawacki-Richter, O., \& Bedenlier, S. (2015). Internationalization of higher education and the impacts on academic faculty members. Journal of Studies in International Education, 10, 185-201.

Zhao, E. (2013). Chinese Students Struggle for Returns on Education in U.S. China Real Time, March 27. 